\title{
Statistical analysis of anthropogenic non-methane VOC variability at a European background location (Jungfraujoch, Switzerland)
}

\author{
V. A. Lanz ${ }^{1, *}$, S. Henne ${ }^{1}$, J. Staehelin ${ }^{2}$, C. Hueglin ${ }^{1}$, M. K. Vollmer ${ }^{1}$, M. Steinbacher ${ }^{1}$, B. Buchmann ${ }^{1}$, and S. Reimann ${ }^{1}$ \\ ${ }^{1}$ Empa, Swiss Federal Laboratories for Materials Testing and Research, Laboratory for Air Pollution and Environmental \\ Technology, 8600 Duebendorf, Switzerland \\ ${ }^{2}$ Institute for Atmospheric and Climate Science, ETH Zurich, 8092 Zurich, Switzerland \\ *now at: Paul Scherrer Institut, Laboratory of Atmospheric Chemistry, 5232 Villigen PSI, Switzerland
}

Received: 11 August 2008 - Published in Atmos. Chem. Phys. Discuss.: 17 November 2008

Revised: 18 May 2009 - Accepted: 20 May 2009 - Published: 28 May 2009

\begin{abstract}
In-situ measurements of 7 volatile hydrocarbons, $\mathrm{C}_{\mathrm{x}} \mathrm{H}_{\mathrm{y}}$, and 3 chlorinated organic compounds, $\mathrm{C}_{\mathrm{x}} \mathrm{H}_{\mathrm{y}} \mathrm{Cl}_{\mathrm{z}}$, were performed at Jungfraujoch (Switzerland) during eight years (2000-2007). The analysis of 4-h resolved non-methane volatile organic compounds (NMVOCs) was achieved by using gas-chromatography coupled with mass spectrometry (GC-MS). Variabilities in the NMVOC time series dataset were modeled by factor analysis (positive matrix factorization, PMF). Four factors defined the solution space and could be related to NMVOC sources and atmospheric processes. In order to facilitate factor interpretations the retrieved contributions were compared with independent measurements, such as trace gases $\left(\mathrm{NO}_{\mathrm{x}}, \mathrm{CO}\right.$, and $\left.\mathrm{CH}_{4}\right)$ and back trajectories. The most dominant factor (accounting on average for $\sim 42 \%$ of the total mixing ratio of the considered NMVOCs) was found to be most active in winter, co-varying with $\mathrm{CO}$ and $\mathrm{CH}_{4}$ and could be related to aged combustive emissions as well as natural gas distribution. The other three factors represent both industrial and evaporative sources. Trajectory statistics suggest that the most influential anthropogenic NMVOC sources for Jungfraujoch are located in Eastern Europe, but the Po Valley has been identified as a potential source region for specific industrial sources as well. Aging of the arriving NMVOCs, the derived factors as well as limitations of the methods are discussed. This is the first report of a PMF application on NMVOC data from a background mountain site.
\end{abstract}

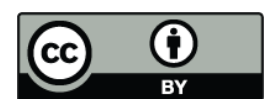

Correspondence to: V. A. Lanz (valentin.lanz@psi.ch)

\section{Introduction}

Measurements of the composition of trace gases at mountain sites, such as the high-alpine observatory at the Jungfraujoch located at $3580 \mathrm{~m}$ a.s.l. in Switzerland, offer unique possibilities because the site is intermittently exposed to air advected from the polluted planetary boundary layer or from the lowermost free troposphere containing lower NMVOC concentrations. The latter properties have been used to study the chemistry of the free troposphere (e.g., Zanis et al., 2003, 2007; Walker et al., 2006; Balzani Lööv et al., 2008; Cozic et al., 2008; Parker et al., 2008) as well as long-term changes of background mixing ratios of trace gases (Reimann et al., 2005, 2008) and tropospheric ozone (Ordoñez et al., 2007). Therefore, Jungfraujoch is a suitable site for background measurements as performed within the Global Atmosphere Watch (GAW) programme of the World Meteorological Organization (WMO) and projects like SOGE (System for observation of halogenated greenhouse gases in Europe). Measurements at Jungfraujoch also provide valuable information to study trace gases as well as aerosols emitted into the planetary boundary layer (e.g. Lugauer et al., 1998). In all such analyses air advected from the planetary boundary layer and air from the free troposphere need to be distinguished. This distinction was performed by different methods using chemical tracers (e.g. Carpenter et al., 2000; Zellweger et al., 2003), meteorological indicators (e.g. Forrer et al., 2000; Henne et al., 2005a), or combinations of both (Henne et al., 2008a). Another method is based on the analysis of backward trajectories of air masses arriving at Jungfraujoch and identification whether or not they were in contact with the planetary boundary layer (e.g., Balzani Lööv et al., 2008). When dealing with the composition of trace gases sampled

Published by Copernicus Publications on behalf of the European Geosciences Union. 
at high mountain sites the changes because of atmospheric oxidation during transport need to be considered as well ( $\mathrm{Li}$ et al., 2005).

In this study, factor analysis (Seber, 1984; Krzanowski, 1988) was applied to organic trace gas measurements at Jungfraujoch. This method explains the variability of trace gas concentrations by a few underlying factors. No prior assumptions, such as meteorological conditions prevailing at the measurement site, are required for this application. Several studies have applied factor analysis and similar multivariate methods to determine emission sources that have an impact on air pollution at selected receptor sites. For example, uncertainty-weighted and positively constrained factor analysis (PMF2; Paatero, 1997) was successfully used to characterize particulate and gaseous emission sources in the planetary boundary layer of an urban background site in Zurich, Switzerland (Lanz et al., 2007, 2008a).

The aim of the present study is to investigate the variability of predominantly anthropogenic NMVOCs at Jungfraujoch. NMVOC time series for the past eight years (2000-2007) are described by means of factor analytical modeling. This study further evaluates the capability and caveats of factor analysis when applied to reactive substances retrieved from remote measurement sites. After the description of the measurements and the applied factor analysis the determined factors are interpreted by making use of simultaneous inorganic air pollutant measurements (nitrogen oxides, $\mathrm{NO}+\mathrm{NO}_{2}$, carbon monoxide, $\mathrm{CO})$, methane $\left(\mathrm{CH}_{4}\right)$ and backward trajectory analysis providing information on potential locations of anthropogenic NMVOC emission sources.

\section{Methods}

\subsection{Measurements}

The high altitude research station Jungfraujoch $\left(7^{\circ} 59^{\prime} \mathrm{E}\right.$, $46^{\circ} 32^{\prime} \mathrm{N}, 3580 \mathrm{~m}$ a.s.l.) is situated on a mountain saddle in the central Swiss Alps between the Jungfrau mountain $(4158 \mathrm{~m}$ a.s.l.) in the West and the Mönch mountain (4099 m a.s.1.) in the East. Because of its high elevation, its central location in Europe, and the proximity to source regions of anthropogenic greenhouse gases measurements at Jungfraujoch can capture both advected air from the polluted boundary layer as well as air from the lower free troposphere (European background).

\subsubsection{NMVOC measurements}

Measurements of NMVOCs are conducted using a fully automated gas-chromatograph (GC) mass-spectrometry (MS) (Agilent 6890 and 5793N) system with a custom-built preconcentration unit (adsorption-desorption system ADS; Simmonds et al., 1995) to allow for sample trapping of $2 \mathrm{~L}$ of air for each measurement. The time span in this study includes eight years of measurements (1 January 2000 to
31 December 2007). The trace gases are collected on a microtrap at $-50^{\circ} \mathrm{C}$ for $40 \mathrm{~min}$ and thermally desorbed at $\sim 240^{\circ} \mathrm{C}$ before they are chromatographically separated on a $120 \mathrm{~m} \times 0.32 \mathrm{~mm}$ I.D. CP-SIL 5CB capillary column (Chrompack) with $5 \mu \mathrm{m}$ film thickness, and detected using single-ion mode quadrupole mass spectrometry.

Air sample measurement runs are completed after $2 \mathrm{~h}$ each and are bracketed by working standard measurements to determine and correct for instrumental drift, resulting in usually six ambient air observations per day. These working standards are prepared by compressing ambient air into $35 \mathrm{~L}$ electropolished stainless steel canisters (Essex Cryogenics, Missouri, USA), by means of a modified oil-free compressor (model SA-3, RIX, California, USA). These working standards are referenced against hydrocarbon standards (National Physical Laboratories, Teddington, UK) and against transfer standards relating the chlorinated NMVOC measurements to the University of Bristol-98 (for dichloromethane and trichloroethene) and the NOAA-2003 (for tetrachloroethene) calibration scales. The mean precisions $(1 \sigma)$ of the Jungfraujoch NMVOC measurements are $<2 \%$ as determined from the precision of the working standard measurements. The accuracies of the results are estimated at $<10 \%$.

The short-lived NMVOCs with atmospheric lifetimes between 2 days and 0.5 year used in this study are summarized in Table 1 (corresponding time series shown in SI-1 http://www.atmos-chem-phys.net/9/3445/2009/ acp-9-3445-2009-supplement.pdf). The organic compounds selected for PMF (Table 1) represent an entity with respect to their origin (primary and predominantly anthropogenic sources) as well as to error calculations (all compounds were measured by the same GC-MS technique). OVOC measurements (including compounds with strong biogenic sources) were only measured during four seasonal campaigns in 2005 (Legreid et al., 2008) and were therefore not included in the study. In this analysis correlations between the inorganic compounds and the PMF factors were used to assist factor interpretation (e.g., see Sect. 3.3).

\subsubsection{Ancillary data}

In order to assist factor interpretations we used continuous long-term in-situ measurements of a comprehensive set of other trace gases at Jungfraujoch which are conducted as part of the Swiss National Air Pollution Monitoring Network (NABEL) operated by Empa in joint collaboration with the Swiss Federal Office for the Environment (FOEN). Carbon monoxide (CO) is monitored via non-dispersive infrared-absorption (APMA 360; Horiba Instruments Ltd) and $\mathrm{NO}_{\mathrm{x}}$ was measured with chemiluminescence detectors (Cranox, CLD 770 AL ppt, Ecophysics) (Zellweger et al., 2000). Methane $\left(\mathrm{CH}_{4}\right)$ has been measured since 2005 by GC with flame ionization detection (GC-FID) (Agilent 6890N) and detailed by Steinbacher et al. (2009). 
Table 1. Mean mixing ratios, $\overline{x_{j}}$, standard deviations, $\operatorname{sd}\left(x_{j}\right)$, in ppt of the 10 considered NMVOC species for the years $2000-2008$ ( $n \sim 60000$ ), and their estimated lifetimes in the atmosphere as calculated from Arey and Atkinson (2003) (hydrocarbons) or derived from McCulloch and Midgley (1996), Kleiman and Prinn (2000), and Ko and Poulet (2003) (chlorinated NMHCs). The last column contains the PMF-explained variability (EV; see Sect. 3.2) of each compound.

\begin{tabular}{lllrrrr}
\hline species $j$ & synonym & formula & $\overline{x_{j}}[\mathrm{ppt}]$ & $\mathrm{sd}\left(x_{j}\right)[\mathrm{ppt}]$ & lifetime & expl. var. (EV) \\
\hline isobutane & 2-methylpropane & $\mathrm{C}_{4} \mathrm{H}_{10}$ & 62 & 59 & $7 \mathrm{~d}$ & $87 \%$ \\
butane & n-butane & $\mathrm{C}_{4} \mathrm{H}_{10}$ & 97 & 114 & $6 \mathrm{~d}$ & $90 \%$ \\
isopentane & 2-methylbutane & $\mathrm{C}_{5} \mathrm{H}_{12}$ & 61 & 68 & $3 \mathrm{~d}$ & $82 \%$ \\
pentane & n-pentane & $\mathrm{C}_{5} \mathrm{H}_{12}$ & 29 & 35 & $4 \mathrm{~d}$ & $85 \%$ \\
dichloromethane & methylene chloride, $\mathrm{DCM}$ & $\mathrm{CH}_{2} \mathrm{Cl}_{2}$ & 42 & 22 & $5-6 \mathrm{mo}$ & $91 \%$ \\
hexane & n-hexane & $\mathrm{C}_{6} \mathrm{H}_{14}$ & 11 & 15 & $3 \mathrm{~d}$ & $76 \%$ \\
benzene & benzol & $\mathrm{C}_{6} \mathrm{H}_{6}$ & 51 & 46 & $12 \mathrm{~d}$ & $85 \%$ \\
trichloroethene & trichlorethylene, TCE & $\mathrm{C}_{2} \mathrm{HCl}_{3}$ & 4 & 6 & $5-11 \mathrm{~d}$ & $97 \%$ \\
toluene & methylbenzene & $\mathrm{C}_{7} \mathrm{H}_{8}$ & 46 & 76 & $2 \mathrm{~d}$ & $88 \%$ \\
tetrachloroethene & perchlorethylene, $\mathrm{PCE}$ & $\mathrm{C}_{2} \mathrm{Cl}_{4}$ & 8 & 8 & $3-7 \mathrm{mo}$ & $88 \%$ \\
\hline
\end{tabular}

\subsection{Data analysis}

\subsubsection{Matrix factorization}

For bilinear mixing models it is assumed that an observed concentration or mixing ratio, $x_{i j}$, can be linearly approximated by $p$ sums of products, $g_{i k} f_{k j}$, up to some error, $e_{i j}$ :

$x_{i j}=\sum_{k} g_{i k} f_{k j}+e_{i j}, i=1 \ldots m, j=1 \ldots n, k=1 \ldots p$,

where $f_{k j}$ represents the $j^{t h}$ species loading in the $k^{t h}$ factor and $g_{i k}$ the score of the $k^{\text {th }}$ factor in the $i^{t h}$ sample. Both $g_{i k}$ and $f_{k j}$ are estimated in this approach. The model equation above can be rewritten in matrix notation as follows

$\mathbf{X}=\mathbf{G F}+\mathbf{E}$,

where $\mathbf{G}$ is an $n \times p$-matrix containing $p$ factor scores or contributions over $n$ samples in time and $\mathbf{F}$ is an $p \times m$-matrix representing $p$ factor profiles including $m$ measured quantities. Paatero and Tapper $(1993,1994)$ showed that principal component analysis (PCA) as a least-square fit to the data matrix elements $x_{i j}$ might be badly weighted and proposed heteroscedastic errors for their model (positive matrix factorization, PMF). Uncertainty values, $\sigma_{i j}$ (based on the measurement error), are estimated for each data point, $x_{i j}$, and are used to weight $\left(w_{i j}=\sigma_{i j}^{-1}\right)$ the residuals, $e_{i j}$ (see Eq. 1), in the chi-square metric:

$Q=\sum_{i} \sum_{j}\left(e_{i j} w_{i j}\right)^{2}$,

where $Q$ is to be minimized with respect to both $g_{i k}$ and $f_{k j}$. The program PMF2 written by Paatero (1997) was designed to solve this task restricting the solution to non-negative values only, which allow for a quantitative interpretation of the factors. The model parameters and uncertainty estimates were specified as described for chromatographic data (GCFID) elsewhere (Lanz et al., 2008a).
Table 2. Coefficients of determination $\left(R^{2}\right)$ for linear regressions of factor contributions vs. ancillary tracers for combustion $(\mathrm{CO}$, $\left.\mathrm{NO}_{\mathrm{x}}, \mathrm{CH}_{4}\right)$ : $[\text { tracer }]_{\mathrm{i}}=\mathrm{a}_{\mathrm{k}} \mathrm{g}_{\mathrm{ik}}+\mathrm{b}_{\mathrm{k}}$. Estimates for $a_{k}$ are all significantly different from 0 on the $p<0.05$ level. Non-zero intercepts $\left(b_{k}>0\right)$ can be calculated for regression models involving $\mathrm{CO}$ $\left(b_{k}=0.10 \ldots 0.12 \mathrm{ppm}\right)$ and $\mathrm{CH}_{4}\left(b_{k}=1.82 \ldots 1.84 \mathrm{ppm}\right) . \quad R^{2} \geq 0.50$ in bold, $R^{2} \geq 0.40$ in italics. ( $n$ : number of observations.)

\begin{tabular}{lllr}
\hline$R^{2}$ & $\begin{array}{l}\mathrm{CO} \\
(n)\end{array}$ & $\begin{array}{l}\mathrm{NO}_{\mathrm{x}} \\
(7202)\end{array}$ & $\begin{array}{r}\mathrm{CH}_{4} \\
(2720)\end{array}$ \\
\hline factor 1 & 0.40 & 0.24 & $\mathbf{0 . 5 0}$ \\
factor 2 & 0.17 & 0.14 & 0.26 \\
factor 3 & 0.22 & 0.43 & 0.22 \\
factor 4 & 0.22 & 0.36 & 0.20 \\
\hline
\end{tabular}

\subsubsection{Data projections}

Henry $(1997,2003)$ has used a geometrical approach to visualize the receptor problem (Eqs. 1 and 2) and to derive starting values for his bilinear unmixing algorithm (UNMIX). It is based on the assumption that there are samples in the data representing pure (or absent) sources. As the measurement site Jungfraujoch is located away from considerable anthropogenic source regions, the factor profiles $\mathbf{F}$ retrieved from anthropogenic NMVOC concentrations can not be expected to equal fresh emission profiles, because of atmospheric oxidation processes altering the composition during transport. In order to check the connection of the PMF-solution with the physical reality we projected the PMF-resolved profiles along with the real NMVOC-samples onto the planes spanned by standardized principal components (PCs) as described below. 

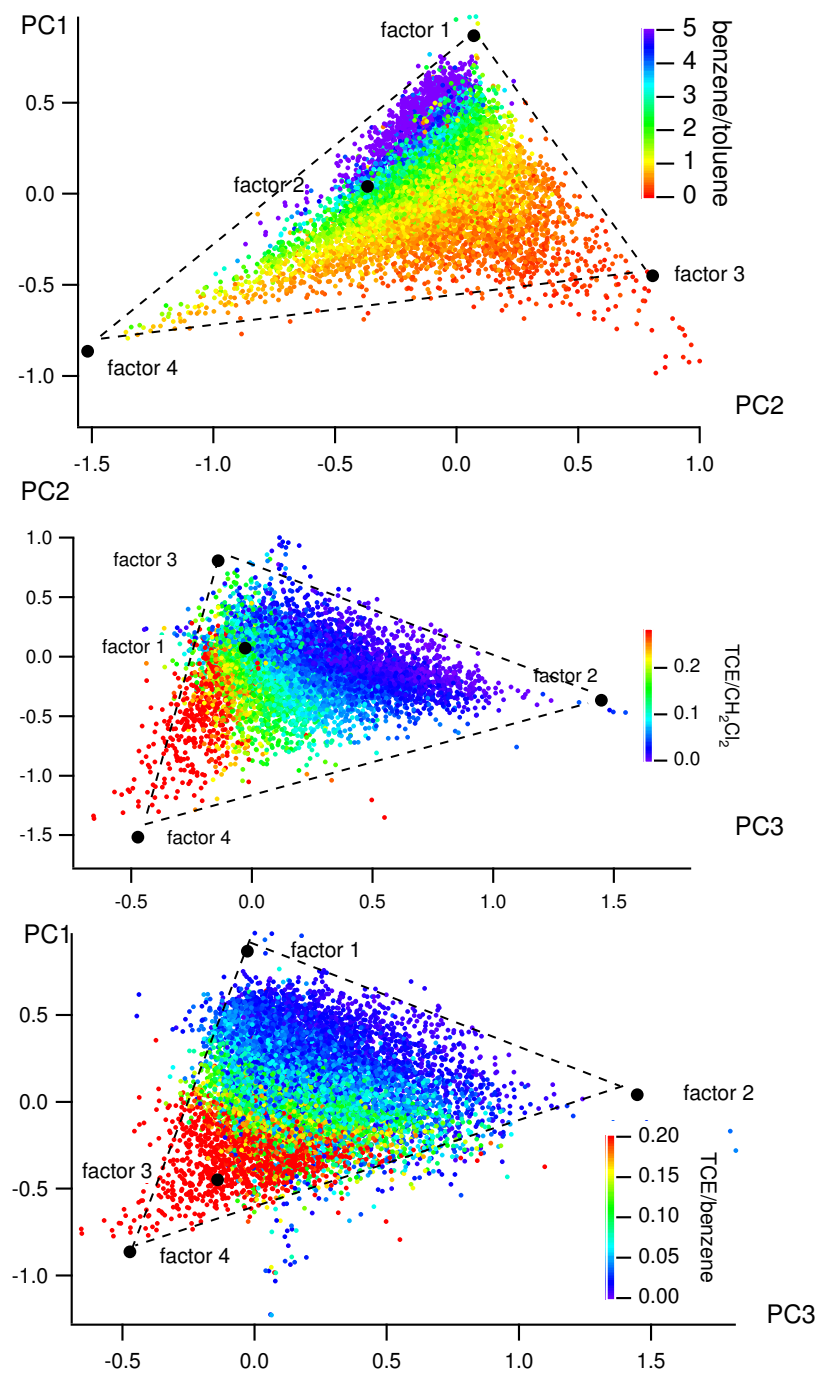

Fig. 1. Data samples $(n \sim 10000)$ and PMF-resolved profiles $(p=4)$ projected onto the standardized PC planes (PC: principal components). The ratio benzene/toluene is shown for samples in the $\mathrm{PC} 1$ vs. PC2 plane (top), the ratio $\mathrm{TCE} / \mathrm{CH}_{2} \mathrm{Cl}_{2}$ for $\mathrm{PC} 2$ vs. $\mathrm{PC} 3$ (middle), and the TCE/benzene-ratio for PC1 vs. PC3 (down) (TCE: trichloroethene).

First, the observables $j$ were divided by their median, $\tilde{\mathbf{X}}:=\mathbf{X}_{i j} /$ median $\left(\mathbf{x}_{j}\right)$, to make their scales comparable (normalization). Then, the PCs of the matrix $\tilde{\mathbf{X}}_{i j}(\operatorname{rank} p<m$ ), which equal $\mathbf{U} \Lambda$, were determined by singular value decomposition (SVD; described in more detail in Golub and Van Loan, 1996):

$\tilde{\mathbf{X}}=\mathbf{U} \Lambda \mathbf{V}^{t}$,

where $\mathbf{U}$ is an $n \times m$-matrix, $\Lambda$ and $\mathbf{V}$ transposed are both orthogonal $m \times m$-matrices. The matrix-product $\mathbf{U} \Lambda$ contains the principal component scores, which are the coordinates of the sources in the space of the principal components. All but the first $p$ diagonal elements in $\Lambda$ were set to 0 to obtain $\Lambda_{p}$ and the standardized scores were calculated as

$\mathbf{G}^{\mathrm{std}}=\mathbf{U} \Lambda_{p} /\left(\mathbf{u}_{j} \lambda_{p=1}\right)$,

Here, $p$ represents the reduced dimensions of the data in $\mathbb{R}^{m}$, the $m$-dimensional subspace. The simplex spanned by the $p$ factors is called solution space. The standardization given in Eq. (5) reduces the dimensionality of the PC coordinate system to $p-1$. These projections also allow to check the dimensionality $p$ as specified within the PMF analysis.

\subsubsection{Trajectory statistics}

For the years 2002-2007, backward air mass trajectories are available for Jungfraujoch ( $48 \mathrm{~h}$ back in time, 6 trajectories per day, arrival altitude at $\sim 100 \mathrm{~m}$ above model ground). These trajectories were computed using the model TRAJEC (Fay et al., 1995) and are based on hourly 3-dimensional wind fields $(7 \mathrm{~km} \times 7 \mathrm{~km}$ horizontal resolution and 45 vertical levels) from the COSMO model. COSMO (Consortium for Small-scale Modeling, http://cosmo-model.cscs.ch/) is an operational numerical weather prediction model operated by MeteoSwiss (Federal Office of Meteorology and Climatology). The arrival altitude of these backward trajectories was $100 \mathrm{~m}$ above model ground or $2750 \mathrm{~m}$ a.s. 1 . which is considerably lower than the physical altitude of Jungfraujoch. When using transport simulations on a finite grid to interpret measurements on mountain top site one needs to decide between improved model skill for short-range or longrange transport. Long-range transport is usually better reflected by trajectories initialised at the actual receptor height which then only experience little surface influence. When focusing on questions of short-range (continental scale) transport and influence of the atmospheric boundary layer trajectories initialised close to model ground resemble local (surface influenced) flow much closer. In this study the focus is on short-range transport from potential European source regions, therefore the arrival altitude at the receptor was set to $100 \mathrm{~m}$ above model ground. The resulting trajectories were loaded with the PMF calculated factor contributions, $g_{i k}$. PMF results were assigned to trajectories if $\Delta t<1.5 \mathrm{~h}$, where $\Delta t$ is the absolute time difference between trajectory arrival and available VOC measurements. In this way 5296 factor contributions were assigned to trajectories and the corresponding mixing ratios were redistributed within the European domain. A grid was superimposed on the domain of the COSMO trajectories. A weighted mean mixing ratio was calculated for each grid cell according to Seibert et al. (1994)

$\bar{g}_{\mathrm{abk}}=\exp \left[\left(\sum_{i} \tau_{\mathrm{abi}}\right)^{-1} \sum_{i} \tau_{\mathrm{abi}} \ln \left(g_{i k}\right)\right]$,

where $\tau_{\mathrm{abk}}$ is the residence time of the $\mathrm{i}^{\text {th }}$ trajectory within the atmospheric boundary layer of grid cell $(a, b)$. The logarithmic transformation was chosen because the distribution 
of the factor contributions was rather log-normal than normal. The atmospheric boundary layer top was defined as a seasonally variable pressure difference between the surface and the boundary layer top and reached from $120 \mathrm{hPa}$ in January to $200 \mathrm{hPa}$ in July. The results are shown for grid cells hit by at least 10 trajectories. This procedure can not be expected to be quantitative, but gives an indication for potential source regions of the considered pollutants (more details can be found in Reimann et al., 2004). Assuming that significant mixing can be ignored for the relatively short transport time the trajectories carry the composition of the dominant emissions sources over Europe covering a temporal range of two days. Depending on transport time from the emission region to Jungfraujoch and $\mathrm{OH}$ concentrations, toluene, the most reactive compound (with an averaged lifetime of 2.4 days, see Table 1) is only partially oxidized.

\section{Results and discussion}

\subsection{Dimensionality and visualization of the PMF- solution}

The determination of the number of factors is not closing for all techniques of dimensionality reduction and receptor models. This holds even more for data collected at remote sites, where the calculated receptor profiles can not be directly related to fresh emission profiles reported in the literature.

We chose four factors ( $p=4$, Eq. 1$)$ to approximate the full data matrix. This solution yields a $Q$-value (see Eq. 3 ) of $\sim 10^{5}$, which is in line with what is expected for an $\mathrm{nm}$ element data matrix $(m=10, n \sim 10000)$. This means that overall the assumed uncertainties $\mathbf{S}$ approximate the model error $\mathbf{E}, \mathbf{S} \approx \mathbf{E}$. This criterion is essentially a mathematical one and does not guarantee that the PMF-solution can be related to physical reality.

In addition, the four factor profiles as calculated with the PMF2 program were appended to the data matrix $\mathbf{X}$ and subject to the data projection as described above (Eqs. 4 and 5). Figure 1 shows the NMVOC measurements projected onto the standardized PC planes along with the 4-factorial PMF solution. The PMF-modeled profiles lie close to the vertices of the facets (defined by $\mathbf{G}^{\text {std }}$ ) in the coordinate system of the standardized PC scores. Therefore, the PMFsolution seems connected with the physical reality, which also clearly reduces its potential rotational uncertainty. From these projections, it can easily be deduced that the PMFsolutions are very close to the vertices of a tetrahedron (i.e. a 3-dimensional simplex defined by the data), supporting the choice of a 4-factorial solution in this application. In other words: the majority of points each representing 10 simultaneous NMVOC observations lie in the triangles of the projections of the factors providing evidence that the four selected factors represent important tropospheric processes determining a large part of the atmospheric variability of the sample. The choice of more factors, $p=5,6,7, \ldots$, results in unrealistic factor profiles representing single species (see Sect. 3.2). In Fig. 1 (top panel) a few samples lie beyond factor 3 (i.e., higher PC2 and lower PC1 scores) allegedly providing a better solution profile. However, these samples exhibit an overwhelming toluene peak and Li et al. (2005) have hypothesized that a local source might cause such events (the presence of such local toluene sources can affect the determination of the absolute and relative photochemical age for the arriving air masses). As indicated by this plot (Fig. 1, top panel), these toluene dominated samples were downweighted in the robust mode of the PMF2 algorithm and do not determine the shape of factor 3 (Fig. 2). If PMF was run in the non-robust mode, these samples would not have been down-weighted and factor 3 would be at $-1.0 / 1.0$ in PC1/PC2-space, Fig. 1, top panel.

The benzene:toluene ratio (as shown for the standardized PC1 scores vs. PC2 scores in Fig. 1, top panel) has been used to calculate a "photochemical age" of the air masses at receptor sites by assuming common sources and constant emission ratios for the two compounds (Roberts et al., 1984). However, as pointed out by McKeen and Liu (1993) this idealistic concept overrides non-linear processes that influence the benzene:toluene ratio in non-isolated air parcels from source to receptor, such as uptake of fresh emissions on the transport path and mixing with background air of variable composition. Therefore, NMVOC ratios can not be expected to provide an accurate absolute age of the arriving air masses, but may serve as a qualitative indication of the age/origin of the air masses. Li et al. (2005) and Lanz et al. (2008c) showed that the benzene:toluene ratio can be indicative for the photochemical age of the arriving air masses at Jungfraujoch, at least for selected periods. However, initial benzene:toluene ratios at emission sources (in VOC source regions) show a large variability in place and time, limiting the use of this ratio as a conclusive and qualitative surrogate for the air masses' age. Hypotheses based on the benzene:toluene ratio of the factors, e.g. the free tropospheric character of factor 1, need to be validated by additional evidence, e.g. given by means of backward trajectory analysis (Sect. 3.3). The top panel in Fig. 1 indicates that factor 1 (aged air masses) and factor 3 (fresh emissions) span the full range of air mass ages observable at Jungfraujoch during 2000-2007. This suggests that these factors are not only indicative for emission sources, but also for atmospheric processes, such as aging of air masses.

A stratification of the samples can also be described by factors 2 and 4 with respect to the trichloroethene:dichloromethane ratio (Fig. 1, middle panel) as well as the trichloroethene:benzene ratio (Fig. 1, lower panel). While the substances of the former ratio have different lifetimes, those of the latter are very similar (Table 1) further questioning the conclusiveness of NMVOC ratios as surrogates for air mass clocks. 
Table 3. Mean source contributions estimates (SCE), mean $\left(g_{i k} / \sum_{j} x_{i j}\right)$, and the standard deviation of the mean in brackets. Seasonal abundance of the contribution as absolute values ( $\mathrm{ppb}$ ) and percentages (\%) (s: summer source, w: winter source). Potential source regions (PSR) in Europe as calculated by trajectory statistics for absolute (ppb) and relative (\%) factor contributions (N: North, S: South, E: East, W: West). Key species in each factor as defined by an explained variation $\left(E V_{k j}\right)>50 \%$ (concept of $E V_{k j}$ see Sect. 3.2). A tentative interpretation of the PMF factors as NMVOC sources is given as well.

\begin{tabular}{lcccccccc}
\hline factor $k$ & SCE $(\%)$ & season $(\mathrm{ppb})$ & season $(\%)$ & correlation & PSR $(\mathrm{ppb})$ & $\mathrm{PSR}(\%)$ & key species & interpretation \\
\hline$k=1$ & $42(0.2)$ & $\mathrm{w}$ & $\mathrm{w}$ & $\mathrm{CH}_{4},(\mathrm{CO})$ & $\mathrm{NE}$ & $\mathrm{NE}$ & (iso-)butane & aged, combustion, (gas distribution) \\
$k=2$ & $28(0.2)$ & $\mathrm{s}$ & $\mathrm{s}$ & - & $\mathrm{SE}$ & $\mathrm{NSEW}$ & $\mathrm{CH}_{2} \mathrm{Cl}_{2}, \mathrm{C}_{2} \mathrm{Cl}_{4}$ & industrial, non-combustion \\
$k=3$ & $19(0.1)$ & - & $\mathrm{s}$ & $\left(\mathrm{NO}_{x}\right)$ & $\mathrm{SE}$ & $\mathrm{S}$ & toluene & fresh, solvent-use \\
$k=4$ & $5(0.1)$ & - & $\mathrm{s}$ & - & $\mathrm{SE}$ & $\mathrm{W}$ & $\mathrm{C}_{2} \mathrm{HCl}_{3}$ & industrial, non-combustion \\
\hline
\end{tabular}

In addition, it should be noted that the sources of benzene and toluene are not identical - the extreme benzene:toluene ratios might simply indicate that factors 1 and 3 represent compositional changes in this respect. This seems plausible as wood burning emissions for instance were characterized by a benzene:toluene ratio of 10 , whereas a ratio of 0.5 or less was estimated for fossil fuel burning (Lanz et al., 2008a). Recent research suggests that wood burning is a seasonally important source of airborne organics in Europe, e.g. in Helsinki (Saarikoski et al., 2008), in Zurich (Lanz et al., 2008b) or in the Alps (Sandradewi et al., 2008; Gaeggeler et al., 2008). On the other hand, many solvents contain toluene but virtually no benzene, yielding a benzene:toluene ratio of $\sim 0$.

\subsection{Factor profiles}

The factor profiles are discussed in terms of explained variability, $E V$,

$$
E V_{k j}:=\sum_{i}\left|g_{i k} f_{k j}\right| /\left(\sum_{i}\left(\sum_{h}\left|g_{i h} f_{h j}\right|+\left|e_{i j}\right|\right)\right),(7)
$$

the relative contribution of each factor $k$ to the individual compounds $j$, as their absolute mixing ratios in ambient air are on different scales and not directly comparable. As in Eq. (1), $f$ represents the factor profiles and $g$ the factor contributions (time series).

Factor 1 explains the variability of $\mathrm{C}_{4}$ and $\mathrm{C}_{5}$ hydrocarbons (isobutane $(56 \%)$, butane $(65 \%)$, pentane $(45 \%)$, isopentane $(30 \%)$ and hexane $(45 \%)$ as well as benzene (46\%), plotted in Fig. 2, right x-axis). Virtually no chlorinated NMHCs are included in this factor. Benzene mixing ratios are over-represented as opposed to fresh emission profiles of both wood and fossil fuel combustion (Lanz et al., 2008a). Benzene is the longest-lived hydrocarbon considered here and, for this reason, factor 1 is interpreted as a (highly) aged combustion and natural gas distribution profile (for an overview of tentative factor interpretations see Table 3). At Jungfraujoch, strongly aged air usually is influenced by air masses from the lowermost free troposphere, particularly in winter. The compounds might be emitted into the planetary boundary layer in other continents and oxidized during intercontinental transport (see e.g Li et al., 2005, and Balzani Lööv et al., 2008).

Factor 3 also explains the variability of mainly hydrocarbon species. But in contrast to the first factor, compounds that can be associated with industrial solvent-use, fresh road traffic-emissions or evaporation, such as iso-pentane $(35 \%)$, pentane $(32 \%)$, hexane $(31 \%)$ and toluene $(70 \%)$ are included in factor 3 . The hydrocarbon profile is very similar ( $\left.R^{2}=0.99, n=7\right)$ to the profile "solvent use" estimated for urban data of Zurich, which is located in the Swiss plateau representing air advected from the polluted planetary boundary layer to Jungfraujoch (Lanz et al., 2008a).

The chlorinated compounds are predominantly distributed to factors 2 and 4 . Factor 2 comprises the long-lived dichloromethane $(70 \%)$ and tetrachloroethene $(56 \%)$. Hydrocarbons play a minor role (and possibly represent mixing with background air): benzene (37\%), isobutane (29\%) etc. The fourth factor explains most of the trichloroethene variability (92\%), and to some minor extent also tetrachloroethene $(20 \%)$ and dichloromethane $(12 \%)$.

The large variability of the measurements of the individual compounds (see Table 1) can be strongly reduced, when described as a linear combination of the 4 factors. Only between $3 \%$ (trichloroethene) and $24 \%$ (hexane) of the variabilities remain unexplained by the model (see Fig. 2 and Tab. 1). Increasing the number of factors to $p=5$ leads to a factor that almost exclusively explains hexane variability $\left(E V_{5 \text {, hexane }}=96 \%\right)$. Assuming even more factors yields additional factors that predominantly explain the variability of individual compounds. This can be explained by the fact that the long-term background variability of individual compounds makes up about half of the computed $Q$ (see Eq. 3). For this calculation, baseline values for each NMVOC species were estimated in analogy to Novelli et al. (1998) and Thoning et al. (1989), subtracted from the NMVOC measurement series, and PMF2 was re-run for these background corrected data (the background mixing ratios of each species were approximated by a polynomial quadratic equation and the window width of the low-pass filter was set to 80 days). This analysis further revealed that the 

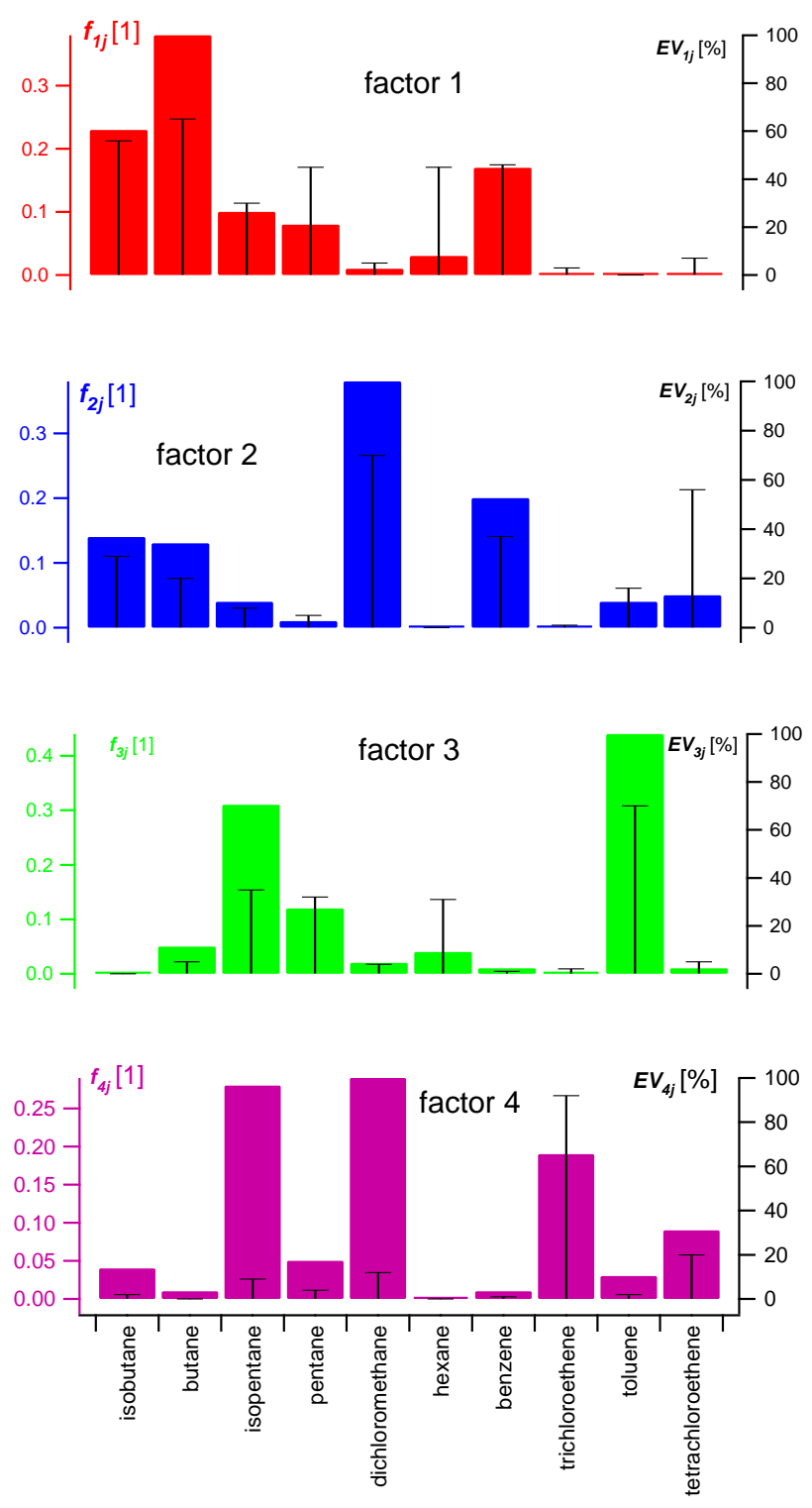

Fig. 2. Factor profiles as calculated by PMF. The factor profiles sum to unity, $f_{k j}[1]:=\sum_{j} f_{k j}=1$, and are indicated by the colored bars (left axis). The variability of each compound that is explained by the $k^{\text {th }}$ factor, EV [\%], is shown on the right axis (whiskers).

differences between the factor profiles calculated for background corrected and uncorrected data are negligible when $p=4$ (or less) factors were prescribed.

\subsection{Factor contributions}

\subsubsection{Seasonality}

The factor contributions, $\mathbf{g}_{i k}$ (time series in $\mathrm{ppb}$ ), are shown in Fig. 3. Monthly boxplots were calculated to represent the seasonally different cycles of the four factors (Fig. 4).
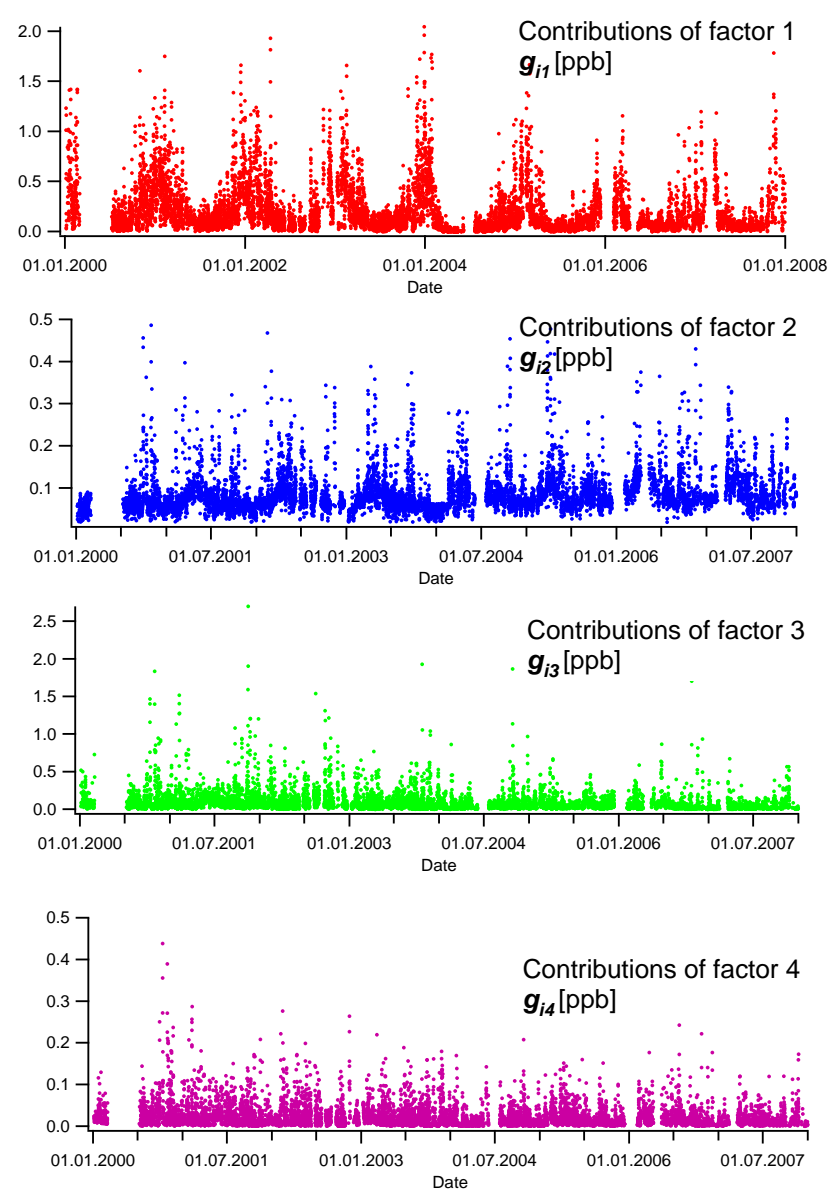

Fig. 3. Time series of the factor contributions as mixing ratios $\mathrm{ppb}$ (derived from NMVOC measurements at Jungfraujoch during 2000-2007; $n \sim 10000$ )

Factor 1 is most important in winter, which is in accordance with the tentative interpretation of influences of lowermost free tropospheric (aged) air and natural gas distribution that occurs dominantly in winter time (see also last paragraph of this section). Factor 2 exhibits the highest mixing ratios in the warm season pointing to the direction of convective processes, which transport primary pollutants from the polluted planetary boundary layer to Jungfraujoch. On the other hand, factor 3 and factor 4 do not show an explicit seasonal cycle for their absolute contributions in ppb (but show summer maxima when their relative contributions in $\% \mathrm{ppb} / \mathrm{ppb}$ are considered). As shown in Fig. 2 most NMVOCs included in the statistical analysis are represented by different factors, e.g. the isobutane mixing ratio makes up a substantial fraction of factor 1-profile $(\sim 25 \%)$, but also in the profile of factor $2(\sim 15 \%)$ and a minor fraction in factor $4(\sim 5 \%)$. Indeed, the classification by PMF allows for further information about NMVOC variability that is not evident from 

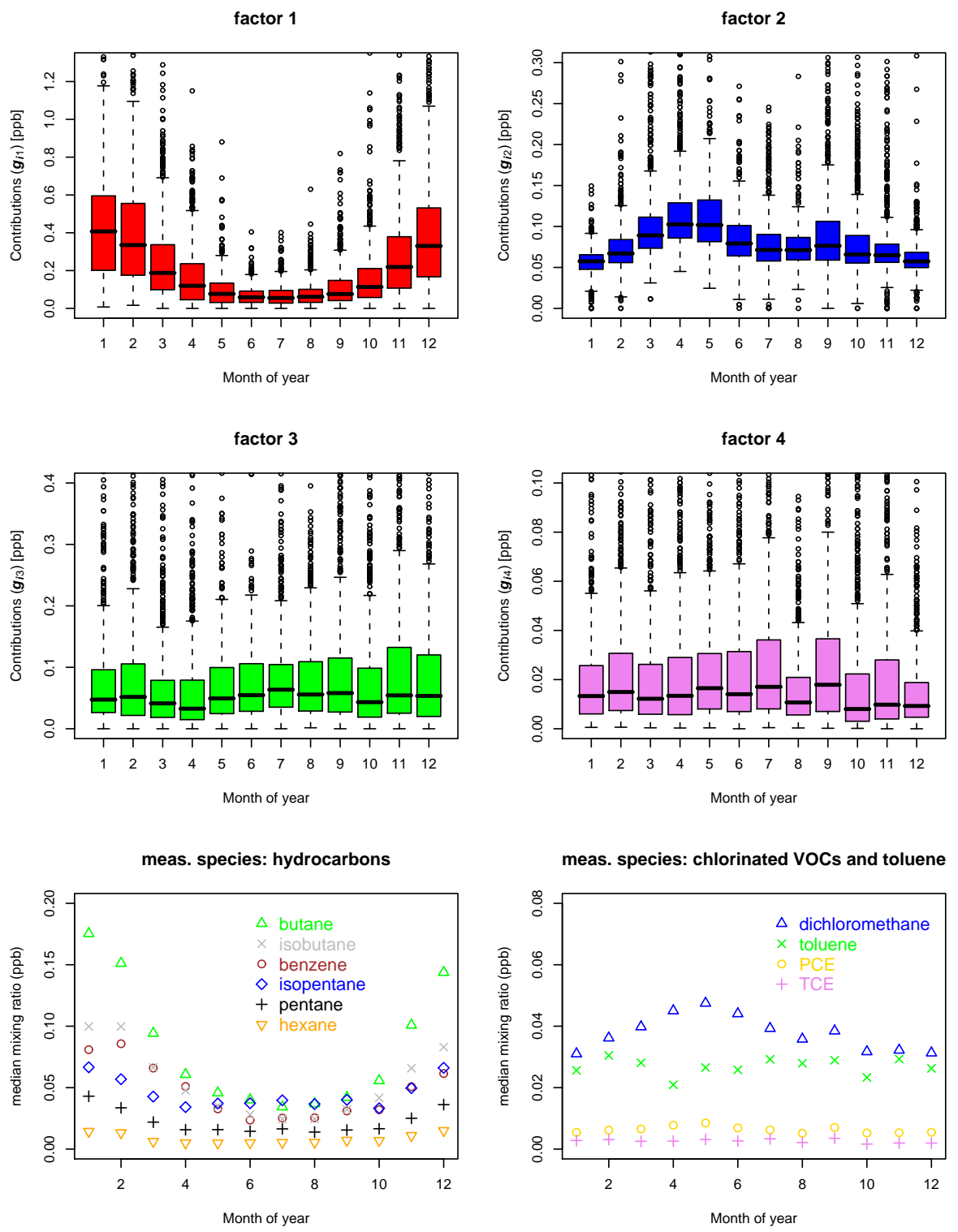

Fig. 4. Monthly boxplots of the four PMF factor contributions in ppb $(n \sim 10000)$. The horizontal bar represents the median, the boxes are confined by the 1 st and 3rd quartile. Circles represent extreme observations. Monthly median values are shown for the observed in-situ measurements of the 10 NMVOCs considered. TCE: trichloroethene, PCE: tetrachloroethene.

separate analyses of single compounds, as all measured hydrocarbons (except toluene) show a yearly cycle with maxima in winter (Fig. 4, lower left panel).

This hydrocarbon accumulation in winter can be observed at several remote sites in the Northern hemisphere, e.g. in Canada (Bottenheim and Shepherd, 1995) or Germany (Klemp et al., 1997) as well as in free tropospheric air analyzed by Balzani Lööv et al. (2008), representing one potential driver of spring maxima of ozone (Monks, 2000). This accumulation may be in part caused by the seasonal variation of hydroxyl radical concentrations $[\mathrm{OH}]$, but also due to more medium-range transport from polluted areas to remote locations in wintertime. Toluene, on the other hand, does not show a distinct seasonal variation (Fig. 4, lower right panel). This is possibly due to its $\mathrm{OH}$ reaction rate-constant high enough to explain the removal of a significant toluene fraction during transport even in winter and/or toluene emissions in nearby Alpine valleys with higher mixing ratios than its background level. The seasonal variation in toluene is relatively small compared to other hydrocarbons with similar atmospheric lifetimes (iso-hexane and iso-butane; cf. Table 2 and Fig. 4). A possible explanation for this seasonal behavior is increased evaporative loss of toluene from solvents in summer (as indicated by the seasonal patterns of factors 2 
methane vs. factor 1 (winter)

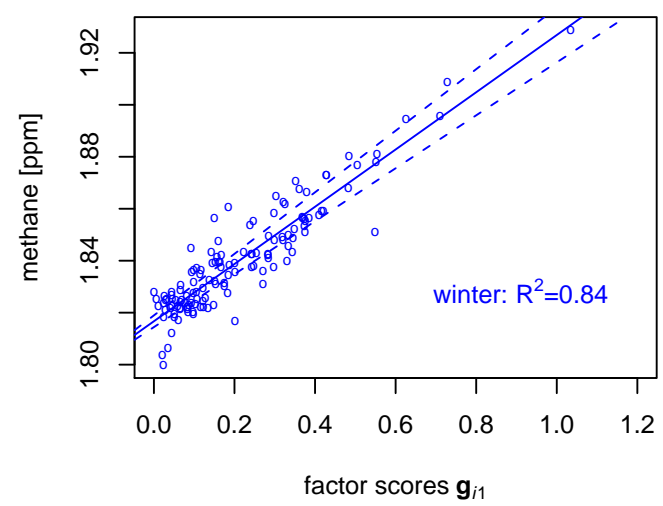

methane vs. factor 1 (summer)

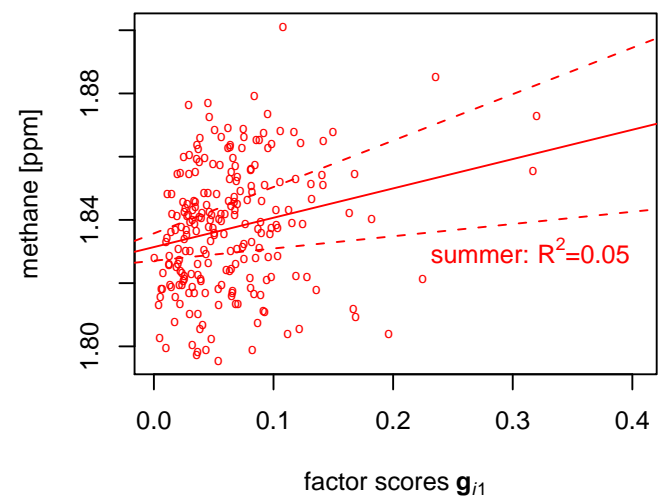

methane vs. factor 1 (spring)

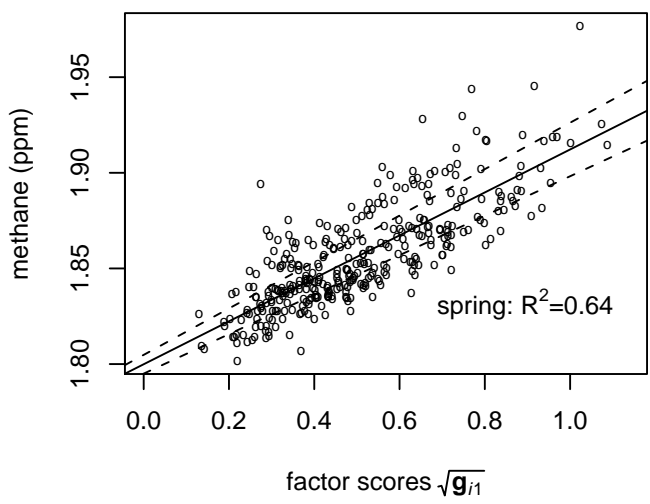

methane vs. factor 1 (autumn)

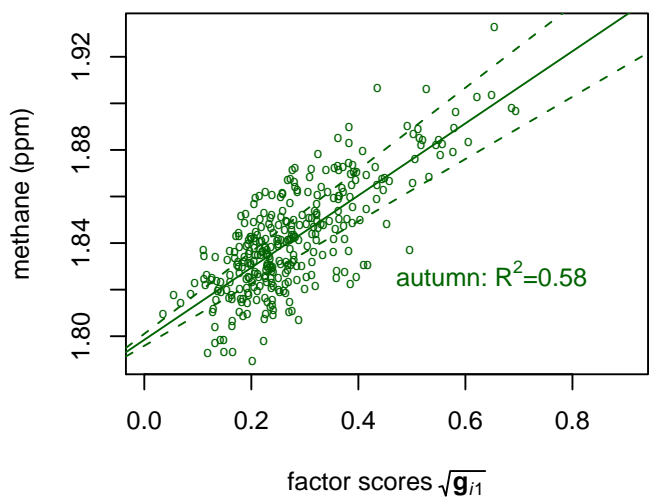

Fig. 5. Scatter plots for methane vs. factor 1: linear regression slopes, intercept, and $\mathrm{R}^{2}$ indicated for winter, spring, summer, and autumn represented by December $(n=132)$, March $(n=346)$, June $(n=223)$, and September $(n=324)$, respectively. For spring and fall months, a square root-transformation of the scores clearly reduces the interdependence of the residuals of the linear regression model and typically increases $R^{2}$. Dashed lines represent the $95 \%$ confidence interval of the regression line.

and 3 in Fig. 4). In addition, contributions from vegetation to toluene in the warm season (as reported for a rural site in the Northeastern US; White et al., 2009) can not be ruled out. This example (i.e., potentially high emissions and relatively rapid removal of toluene) illustrates that the equation of factor contributions with emission source strengths can be impaired at remote sites for substances with variable reactivity or interception efficiencies. In other words, the retrieved factors might be interpreted rather as characteristic NMVOC compositions than fresh emission profiles. Nevertheless, the average transport time of air masses is estimated to be $\sim 0.5$ day (see below), whereas the atmospheric lifetime of the most labile species analyzed in this study (toluene) is five times higher. We therefore conjecture that, overall, the NMVOC variability is driven by both source activities and chemical degradation.
The three considered chlorinated NMVOCs (represented in factors 2 and 4) show maxima in the warm season, highlighting their use as evaporative solvents as well as the higher impact of the industrialized Po Valley nearby on trace gas levels at Jungfraujoch during the warmer season (as mentioned in Seibert et al., 1998, and in Henne et al., 2005b).

In summer, transport times of polluted PBL air towards Jungfraujoch are strongly reduced due to higher PBL top, enhanced convection and thermally induced circulation systems in mountainous terrain, outweighing the enhanced $\mathrm{OH}$-chemistry on Jungfraujoch: the air masses arriving at Jungfraujoch are more (photochemically) aged in winter than in summer (Baltensperger et al., 1997; Nyeki et al., 1998; Zellweger et al., 2003a, 2003b; Henne et al., 2005a), which is different for sites that are within the PBL throughout the year. Therefore, it is plausible that a factor representing aged combustion and natural gas distribution (factor 1) is enhanced in winter. 

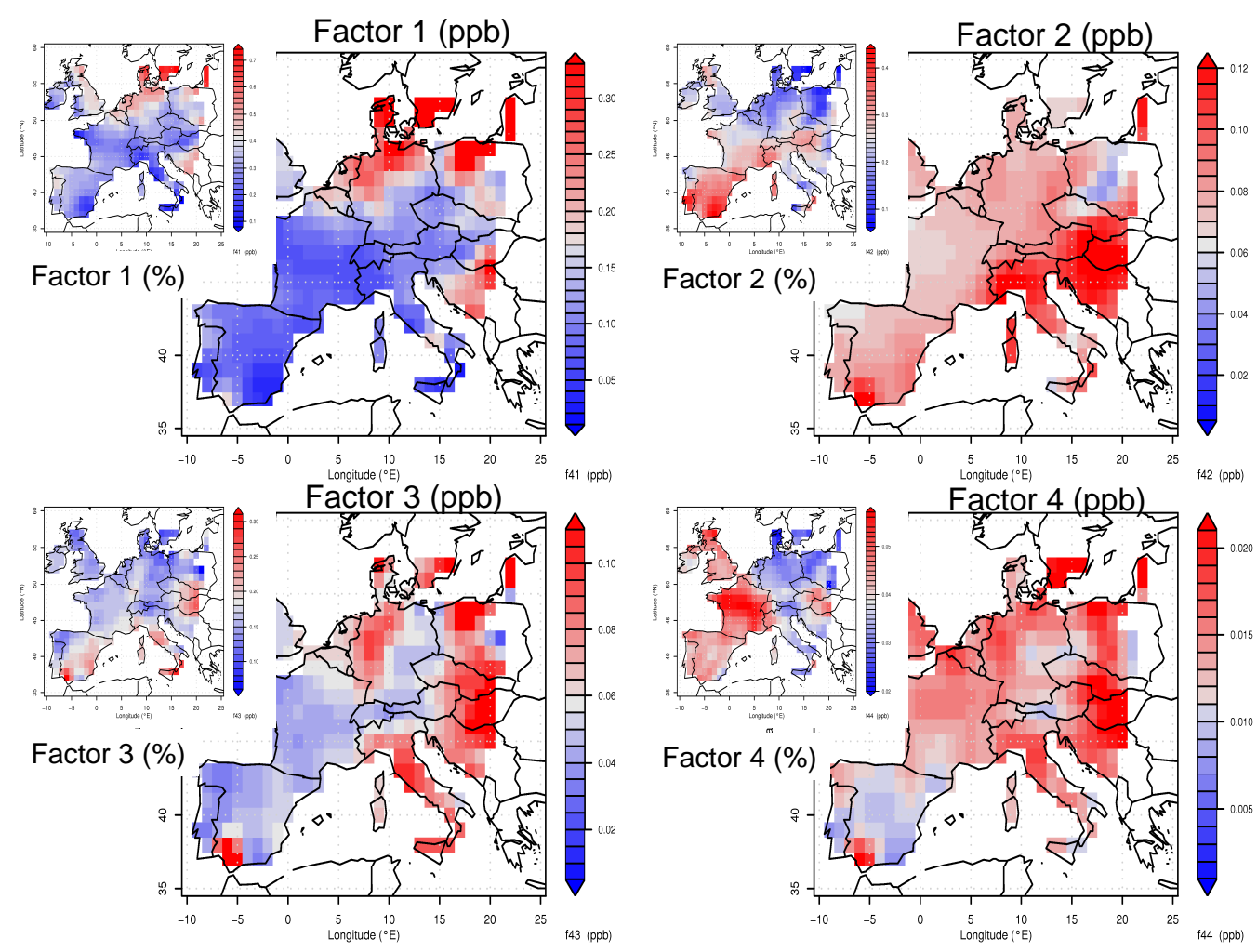

Fig. 6. Trajectory statistics calculated for the contributions (ppb) of four factors. Back trajectories were calculated based on COSMO weather forecasts ( 2 days). The inserted figures show the trajectory statistics for the relative source strengths $(\%)$ of the factors. The number of considered trajectory-measurement pairs was $N=5296$.

\subsubsection{Correlation with gaseous tracers of primary combustion}

We have hypothesized that factor 1 represents an aged combustion profile (Sect. 3.2). Indeed, its contributions are correlated with other long-lived gaseous combustion tracers such as $\mathrm{CO}$ and $\mathrm{CH}_{4}$ (Table 2). The correlation of factor 1 with methane exhibits a strong seasonal dependence, ranging from rather weak $\left(R^{2}=0.05 \ldots 0.44\right)$ in summer months (June, July, August) up to $R^{2}=0.84 \ldots 0.90$ in winter months (December, January, February) - intermediate values can be calculated for months in spring $\left(R^{2}=0.41 \ldots 0.64\right)$ and fall $\left(R^{2}=0.58 \ldots 0.85\right)$. Interestingly, in spring and fall months this relationship is more adequately represented for squareroot transformed factor contributions (comp. Fig. 5). In summer (low correlations), an even higher fractional contribution of natural sources to methane can be expected compared to winter (Denman et al., 2007), e.g. caused by increased biological methanogenesis in soils or plants, which was found to be positively correlated with ambient temperature (Vigano et al., 2008). In contrast, the NMVOCs defining factor 1 originate from anthropogenic activities. In addition, the absence of pollution events in the summery season may explain this trend, but no such strong seasonality could be observed for the correlation with $\mathrm{CO}\left(R^{2}=0.40\right.$ on average $)$, which - in contrast to methane - is released predominantly by anthropogenic sources throughout the whole year (Mészáros et al., 2004).

In contrast to the first factor, factor 2 seems uncorrelated with these latter trace gases and also with $\mathrm{NO}_{\mathrm{x}}$, which together with the findings in the previous chapter, indicate an industrial, non-combustive source for factor 2-species.

\subsubsection{Potential source regions}

A statistical analysis of the trajectories assigned to PMF factor contributions was performed to deduce potential source regions of the NMVOCs (comp. Sect. 2.2.3). Factor contributions (in mixing ratios, ppb) were redistributed within Europe following the approach by Seibert et al. (1994). The resulting maps (Fig. 6) show potential source strengths in ppb and were calculated for the European continent (plus large islands), as comparatively low emissions from the sea can be expected. However, absolute mixing ratios might not always be suitable to derive distinct potential source regions: clean air is transported rapidly from the Atlantic Ocean to Jungfraujoch, strongly diluting the NMVOCs emitted in France. This is different for air from Eastern Europe that 

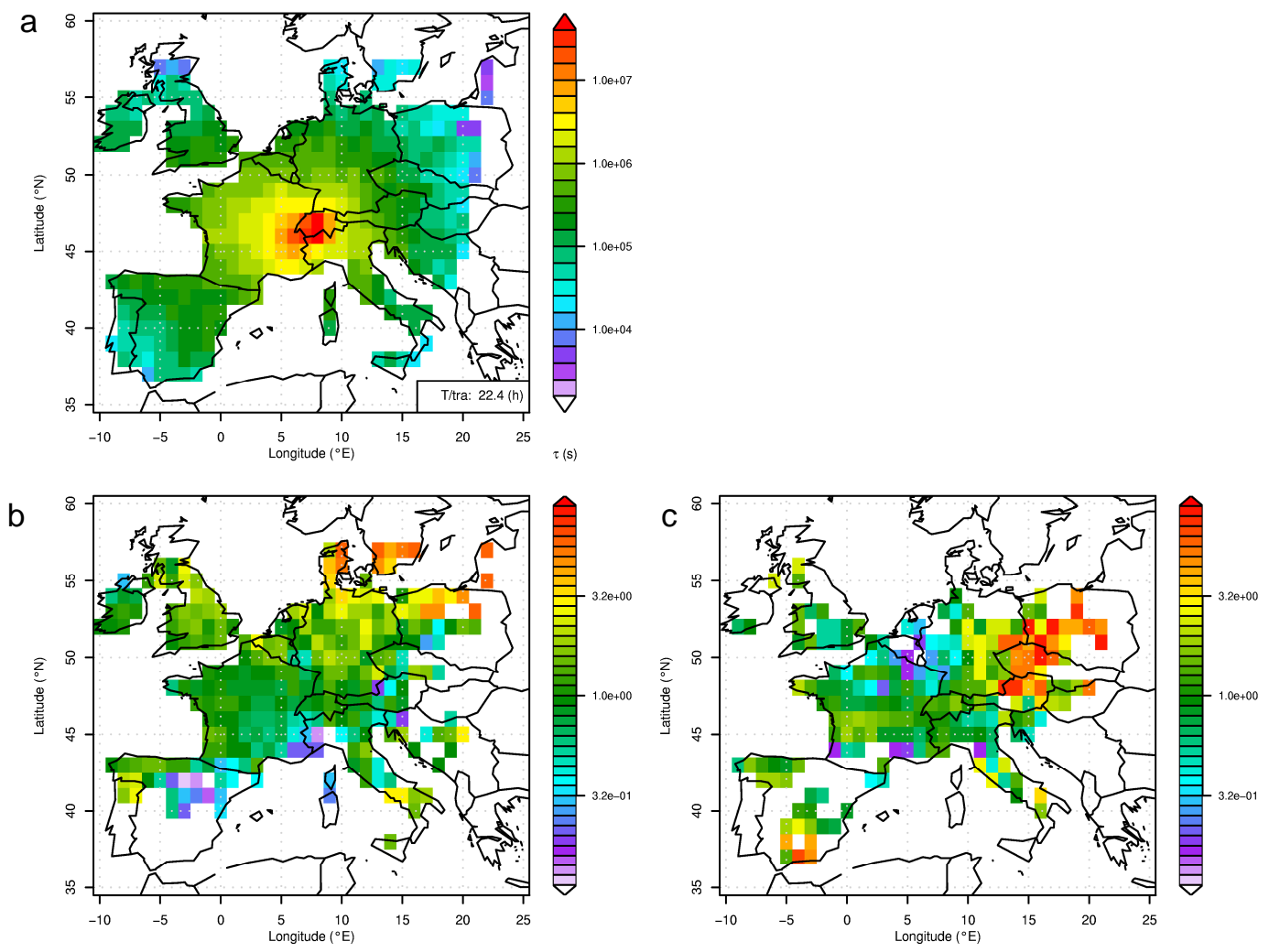

Fig. 7. (a) Total boundary layer residence time of all $N=5296$ trajectories, (b) relative average boundary layer time of trajectories arriving at times when factor 1 dominated (i.e. contributed $>66 \%)$ the measurements $(N=842$; see text for details) and (c) when factor 2 dominated $(N=291)$. On the relative scale a value below 1 indicates less than average surface contact within a grid cell, while values larger than 1 show more than average surface contact. Factors 3 and 4 dominated in less than ten cases and are not shown here.

may be characterized by high pollution levels already when entering Europe. Thus, trajectory statistics based on absolute mixing ratios may be biased towards Eastern sources in the case of Jungfraujoch. In considering this fact, maps generated with redistributed relative contributions defined by $\mathrm{r}_{i k}=\mathrm{g}_{i k} / \sum_{k=1}^{4} g_{i k}$ (in $\% \mathrm{ppb} / \mathrm{ppb}$ ) can be instructive as well and are actually shown as smaller inserts in Fig. 6 and discussed below. All trajectories assigned to NMVOC measurements $(N=5296)$ were in contact with the planetary boundary layer for at least $20 \mathrm{~min}$, but on average for $22.4 \mathrm{~h}$. More than $90 \%$ of the assigned trajectories had boundary layer contact outside Switzerland.

The sources of factor 1-species are potentially located in the Netherlands, Eastern Europe, Southern Italy, and England. These regions are known for their anthropogenic emissions as also corroborated by the EDGAR inventory for anthropogenic $\mathrm{CH}_{4}$-emissions in Europe (http://www.mnp.nl/edgar/model/v32ft2000edgar/ edgv32ft-ghg/edgv32ft-ch4.jsp) that identifies the same areas as strong methane source regions. Thus, the identification of these source regions points to gas/oil distribution, combustion etc. or wood burning as sources related to factor 1 . Furthermore, the same regions show relatively strong CO- emissions as can be derived from the EMEP emission inventory; http://www.ceip.at. It is also evident that contributions from border regions of Europe are enhanced (Fig. 6). Based on the used type of back trajectories, which were limited to the western and central European domain, we can not rule out that these emissions also originate from outside this domain, for example Russia or also North America. This together with the high benzene:toluene ratios (Sect. 3.1) suggests that factor 1 may not only reflect source activity, but possibly aging as well: factor 1 presumably also reflects medium-range transport of the pollutants. High emissions from southern Scandinavia as well could be inferred from Fig. 6, however this allocation is more uncertain: the total residence time of the back trajectories in the boundary layer of that latter region is about two magnitudes lower than for instance in Northern Italy. It is noteworthy that no strong sources were assigned within and close to Switzerland emphasising the more aged (free tropospheric) character of factor 1. This is also underlined by Fig. 7 in which total boundary layer residence times for all trajectories are compared to total boundary layer residence times of trajectories that were dominated $\left(\mathrm{r}_{i k}>2 / 3\right)$ by factor 1 and 2 , respectively. Total residence times for all trajectories (Fig. 7a) showed a relatively uniform circular 
distribution around the receptor site with a bias towards westerly advection. At times when factor 1 dominated the measurements the trajectories had relatively little residence time close to the receptor site. There was especially little boundary layer contact in Northern Italy (Fig. 7b). More than average residence times were indicated in Northern Germany and around the Western Baltic Sea. The average total residence time of these trajectories within the European boundary layer was $17.3 \mathrm{~h}$ in comparison to $22.4 \mathrm{~h}$ for all trajectories, again indicating the more free tropospheric character of factor 1 . Cases in which factor 1 dominated were mainly observed during the winter when Jungfraujoch is usually only weakly affected by input from the regional PBL (Balzani Lööv et al., 2008).

Factor 2 is dominated by hydrocarbons mainly used for industrial purposes, e.g. dichloromethane as a solvent. High factor 2 contributions as well can be associated with anthropogenic emission sources located in Eastern Europe, but an additional source region is the highly industrialized Po Valley. Also Southern Spain is a candidate as a potential source region for factor 2, but given its more remote location, the trajectory statistics are more uncertain in this case (again, the total trajectory residence time per grid cell is about two magnitudes lower than e.g. in Northern Italy.) When factor 2 dominated the measurements the trajectories showed enhanced residence time over Poland, the Czech Republic and Eastern Austria (Fig. 7c); these cases mainly occurred mainly in summer. Contributions were also slightly enhanced over central France and about average from Northern Italy. On average these trajectories had spent $26.6 \mathrm{~h}$ within the European boundary layer, significantly longer than factor 1 dominated trajectories.

The potential source regions for factor 3 and 4 contributions as calculated by using absolute contributions in ppb are almost identical (see Fig. 6). Factor 3 contributes the largest NMVOC fraction (relative contributions, $\% \mathrm{ppb} / \mathrm{ppb}$ ) when air masses are arriving from the South (see Fig. 6, inserted maps). This nicely corroborates the anticipated solvent-use (see Sect. 3.2) and hence temperature-dependent emissions of the relative factor contributions. Conversely, factor 4 (dominated by trichloroethene variability) contributions are most abundant when air masses are arriving from the Western sector (France/Atlantic Ocean), hinting at a distinct region of industrial sources - although potential oceanic emissions of trichloroethene have also been reported, e.g. by natural sources such as seawater algae (Dimmer et al., 2003; Abrahamsson et al., 1995; Khalil, 1999).

\section{Conclusions}

Four factors describing the variability of predominantly manmade NMVOCs with intermediate atmospheric lifetimes (2 days to 6 months) at Jungfraujoch, Switzerland, were derived by positively constrained matrix factorization (PMF).
The calculated factor contributions were loaded on backward trajectories to estimate potential source regions and compared with ancillary data to infer further source information. Particular properties and source information could be associated with the estimated factors, which are not deducible by separate analyses of single compounds. Factors 1 and 3 mainly explain the $\mathrm{C}_{\mathrm{x}} \mathrm{H}_{\mathrm{y}}$ variabilities. While factor 1 explains aged combustion- and natural gas distribution-related NMVOCs, factor 3 covers NMVOCs associated with fresh emissions and solvent-use. Correspondingly, factor 1 is correlated with $\mathrm{CO}$ and $\mathrm{CH}_{4}$ (probably anthropogenic $\mathrm{CH}_{4}$ as its source regions match the anthropogenic $\mathrm{CH}_{4}$ emissions), whereas factor 3 is rather correlated with $\mathrm{NO}_{\mathrm{x}}$, a tracer for fresh emissions. The variability in chlorinated compounds $\left(\mathrm{C}_{\mathrm{x}} \mathrm{H}_{\mathrm{y}} \mathrm{Cl}_{\mathrm{z}}\right)$ is covered by factors 2 and 4 . While both factors can be associated with industrial VOC use in Northern Italy and Eastern Europe, the contributions of factor 4 (key species $\mathrm{C}_{2} \mathrm{HCl}_{3}$ ) are relatively high when air arrives from the West at Jungfraujoch. No such dependency can be observed for factor 2 (key species $\mathrm{CH}_{2} \mathrm{Cl}_{2}, \mathrm{C}_{2} \mathrm{Cl}_{4}$ ).

However, the conclusions are only valid for the chosen VOC subset (non-methane hydrocarbons and chlorinated VOCs). The impact of various sources on total gas-phase organics (t-NMVOC) can not be inferred from the present study: clearly, sources that emit comparatively high proportions of OVOCs (e.g. biogenic sources and biomass burning; Shim et al., 2007; Gaeggeler et al., 2008) are underestimated by these analyses regarding t-NMVOC. Legreid et al. (2008) found that OVOCs including methanol, formaldehyde, and acetone dominate t-NMVOC concentrations at Jungfarujoch. However, these measurements were only performed during four seasonal campaigns in 2005 and therefore not included in our study.

A factor representing highly aged combustive emissions and losses from natural gas distribution accounts for $42 \%$ $\mathrm{ppb} / \mathrm{ppb}$ of the mixing ratio of all 10 NMVOCs considered (factor 1). It is correlated with $\mathrm{CO}$ (representing a tracer of anthropogenic emissions) and with $\mathrm{CH}_{4}$, especially in wintertime when natural sources make the smallest contribution. High factor 1 activities found in winter coincided with air masses arriving from Eastern Europe, Benelux, Southern Italy and England. Interestingly, these regions overlap with the hotspots of anthropogenic methane emissions in Europe (relating factor 1 to natural gas-combustion). However, the factor attributed to aged combustion (factor 1) and another hydrocarbon-dominated, but solvent-like factor (factor 3) also represent extreme benzene:toluene ratios (Fig. 1): we therefore believe that these factors, derived for remote NMVOC observations, also represent differently aged air masses. In contrast to measurements close to anthropogenic sources (Lanz et al., 2008a), this finding suggests that NMVOC variability at Jungfraujoch may not only be influenced by source activities, but also by chemical processing though factors 2 and 4 cannot be associated with air mass ages (determined based on benzene:toluene ratios). 
Factor 2 (28\% ppb/ppb of considered NMVOCs) mostly represents dichloromethane and tetrachloroethene, which are predominantly released by industrial solvent-use and production (Cox et al., 2003). Factor 2 is most active in the warm season and, furthermore, rather uncorrelated with tracers of combustive processes $\left(\mathrm{CO}, \mathrm{NO}_{\mathrm{x}}\right.$, and $\left.\mathrm{CH}_{4}\right)$. Trajectory statistics indicate that its potential source regions are Northern Italy and (as for all anthropogenic NMVOC sources) Eastern Europe, which both harbor manufacturing industries. Relative factor contributions loaded on back trajectories provided additional information, indicating distinct source regions in the West and South for factor 3 and factor 4, respectively.

Most individual NMVOCs and the contributions of three out of four factors decreased from the years 2000-2001 to 2006-2007. The strengths of this decrease (in \% ppb) seems somewhat related to the lifetimes of the species included in each factor, ranging from $-31 \% \ldots-38 \%$ (factors 1 and 4 ) to $-52 \%$ (factor 3 ). For factor 2 , on the other hand, an increase by $30 \%$ can be estimated for the same period, reflecting increasing dichloromethane and tetrachloroethene mixing ratios in recent years. The effect of European NMVOC regulation policies might be overruled by increasingly higher global emissions, which is observable at Jungfraujoch only for the longest-lived substances of the considered NMVOCs.

Acknowledgements. The authors gratefully acknowledge P. Kaufmann (MeteoSwiss) for computing and providing the COSMO trajectories. We thank the International Foundation High Altitude Research Stations Jungfraujoch and Gornergrat (HFSJG) for the opportunity to perform experiments on the Jungfraujoch. These measurements in the Swiss Program HALCLIM are supported by the Swiss Federal Office for the Environment, FOEN. We are grateful to U. Lohmann (ETH Zurich) and A. Prevot (PSI) for helpful comments.

Edited by: T. Karl

\section{References}

Abrahamsson, K., Ekdahl, A., Collén, J., and Pedersén, M.: Marine algae - A source of trichloroethylene and perchloroethylene, Limnol. Oceanogr., 40, 1321-1326, 1996.

Atkinson, R. and Arey, J.: Atmospheric degradation of volatile organic compounds, Chem. Rev., 103, 4605-4638, 2003.

Baltensperger, U., Gaeggeler, H. W., Jost, D. T., Lugauer, M., Schwikowski, M., Weingartner, E., and Seibert, P.: Aerosol climatology at the high-alpine site Jungfraujoch, Switzerland, J. Geophys. Res., 102, 19707-19715, 1997.

Balzani Lööv, J. M., Henne, S., Legreid, G., Staehelin, J., Reimann, S., Prévôt, A. S. H., Steinbacher, M., and Vollmer, M. K: Background concentrations of trace gases at the Swiss alpine site Jungfraujoch (3580 m a.s.1.), J. Geophys. Res., 113, D22305, doi:10.1029/2007JD009751, 2008.

Carpenter, L. J., Green, T. J., Mills, G. P., Bauguitte, S., Penkett, S. A., Zanis, P., Schuepbach, E., Schmidbauer, N., Monks, P. S., and Zellweger, C.: Oxidized nitrogen and ozone production efficiencies in the springtime free troposphere over the Alps, J. Geophys. Res., 105(D11), 14547-14559, 2000.

Cox, M. L., Sturrock, G. A., Fraser, P. J., Siems, S. T., Krummel, P. B., and O'Doherty, S.: Regional sources of methyl chloride, chloroform and dichloromethane identified from AGAGE observations at Cape Grim, Tasmania, 1998-2000, J. Atmos. Chem., 45, 79-99, 2003.

Cozic, J., Verheggen, B., Weingartner, E., Crosier, J., Bower, J. N., Flynn, M., Coe, H., Henning, S., Steinbacher, M., Henne, S., Coen, M. C., Petzold, A., and Baltensperger, U.: Chemical composition of free tropospheric aerosol for $\mathrm{PM}_{1}$ and coarse mode at the high alpine site Jungfraujoch, Atmos. Chem. Phys., 8, 407423, 2008, http://www.atmos-chem-phys.net/8/407/2008/.

Denman, K. L., Brasseur, G., Chidthaisong, A., Ciais, P., Cox, P. M., Dickinson, R. E., Hauglustaine, D., Heinze, C., Holland, E., Jacob, D., Lohmann, U., Ramachandran, S., da Silva Dias, P. L., Wofsy, S. C., and Zhang, X.: Couplings Between Changes in the Climate System and Biogeochemistry, in: Climate Change 2007: The Physical Science Basis. Contribution of Working Group I to the Fourth Assessment Report of the Intergovernmental Panel on Climate Change, edited by: Solomon, S., Qin, D., Manning, M., Chen, Z., Marquis, M., Averyt, K. B., Tignor, M., and Miller, H. L., Cambridge University Press, Cambridge, UK and New York, NY, USA, 2007.

Dimmer, C. H., McCulloch, A., Simmonds, P. G., Nickless, G., Bassford, M. R., and Smythe-Wright, D.: Tropospheric concentrations of the chlorinated solvents, tetrachloroethene and trichloroethene, measured in the remote Northern Hemisphere, Atmos. Environ., 35, 1171-1182, 2001.

Fay, B., Glaab, H., Jacobsen, I., and Schrodin, R.: Evaluation of Eulerian and Lagrangian atmosphere transport models at Deutscher Wetterdienst using ANATEX surface tracer data, Atmos. Environ., 29, 2485-2497, 1995.

Forrer, J., Rüttimann, R., Scheiter, D., Fischer, A., Buchmann, B., and Hofer, P.: Variability of trace gases at the high-Alpine site Jungfraujoch by meteorological transport processes, J. Geophys. Res., 105(D10), 12 241-12 251, 2000.

Gaeggeler, K., Prévôt, A. S. H., Dommen, J., Legreid, G., Reimann, S., and Baltensperger, U.: Residential wood burning in an Alpine valley as a source for oxygenated volatile organic compounds, hydrocarbons and organic acids, Atmos. Environ., doi:10.1016/j.atmosenv.2008.07.038), in press, 2008

Golub, G. H. and Van Loan, C. F.: Matrix Computations (Third Edition), The Johns Hopkins University Press, Baltimore, MD, USA, 1996.

Henne, S., Furger, M., and Prévôt, A. S. H.: Climatology of mountain venting-induced elevated moisture layers in the lee of the Alps, J. Appl. Meteorol., 44, 620-633, 2005a.

Henne, S., Dommen, J., Neininger, B., Reimann, S., Staehelin, J., and Prévôt, A. S. H.: Ozone production following mountain venting studied with a Lagrangian chemistry box-model, J. Geophys. Res., 110, D22307, doi:10.1029/2005JD005936, 2005 b.

Henne, S., Junkermann, W., Kariuki, J. M., Aseyo, J., and Klausen, J.: The establishment of the Mt. Kenya GAW station: installation and meteorological characterization, J. Appl. Meteorol. Clim., 47, 2946-2962, 2008a.

Henne, S., Klausen, J., Junkermann, W., Kariuki, J. M., Aseyo, J. O., and Buchmann, B.: Representativeness and climatology of carbon monoxide and ozone at the global GAW station Mt. 
Kenya in equatorial Africa, Atmos. Chem. Phys., 8, 3119-3139, 2008b, http://www.atmos-chem-phys.net/8/3119/2008/.

Henry, R. C.: History and fundamentals of multivariate air quality receptor models, Chemometr. Intell. Lab., 37, 37-42, 1997.

Henry, R. C.: Multivariate receptor modelling by N-dimensional edge detection, Chemometr. Intell. Lab., 65, 179-189, 2003.

Keene, W. C., Khalil, M. A. K., Erickson, D. J., McCulloch, A., Graedel, T. E., Lobert, J. M., Aucott, M. L., Gong, S. L., Harper, D. B., Kleiman, G., Midgley, P. and Moore, R. M., Seuzaret, C., Sturges, W. T., Benkovitz, C. M., Koropalov, V., Barrie, L. A., and Li, Y. F.: Composite global emissions of reactive chlorine from anthropogenic and natural sources: Reactive Chlorine Emissions Inventory, J. Geophys. Res., 104(D7), 8429-8440, 1999.

Khalil, M. A. K.: Reactive chlorine compounds in the atmosphere, in: Reactive Halogen Compounds in the Atmosphere, edited by: Fabian, P. and Singh, O. N., Springer, New York, USA, 45-79, 1999.

Kleiman, G. and Prinn, R. G.: Measurement and deduction of emissions of trichloroethene, tetrachloroethene, and trichloromethane (chloroform) in the northeastern United States and southeastern Canada, J. Geophys. Res., 105(D23), 28875-28893, 2000.

Klemp, D., Kley, D., Kramp, F., Buers, H. J., Pilwat, G., Flocke, F., Pätz, H. W., and Volz-Thomas, A.: Long-Term Measurements of Light Hydrocarbons $\left(\mathrm{C}_{2}-\mathrm{C}_{5}\right)$ at Schauinsland (Black Forest), J. Atmos. Chem., 28, 135-171, 1997.

Ko, M. K. W. and Poulet, G.: Very short-lived halogens and sulfur substances, in Scientific Assessment of Ozone Depletion: 2002, Global Ozone Res. and Monit. Proj. Rep., 47, chap. 2, 2.1-2.57, World Meteorol. Organ., Geneva, Switzerland, 2003.

Krzanowski, W. J.: Principles of multivariate analysis: a user's perspective, Clanderon Press, Oxford, UK, 1988.

Lanz, V. A., Alfarra, M. R., Baltensperger, U., Buchmann, B., Hueglin, C., and Prévôt, A. S. H.: Source apportionment of submicron organic aerosols at an urban site by factor analytical modelling of aerosol mass spectra, Atmos. Chem. Phys., 7, 15031522, 2007, http://www.atmos-chem-phys.net/7/1503/2007/.

Lanz, V. A., Hueglin, C., Buchmann, B., Hill, M., Locher, R., Staehelin, J., and Reimann, S.: Receptor modeling of $\mathrm{C}_{2}-\mathrm{C}_{7}$ hydrocarbon sources at an urban background site in Zurich, Switzerland: changes between 1993-1994 and 2005-2006, Atmos. Chem. Phys., 8, 2313-2332, 2008a,

http://www.atmos-chem-phys.net/8/2313/2008/.

Lanz, V. A., Alfarra, M. R., Baltensperger, U., Buchmann, B., Hueglin, C., Szidat, S., Wehrli, M. N., Wacker, L., Weimer, S., Caseiro, A., Puxbaum, H., and Prévôt, A. S. H.: Source attribution of submicron organic aerosols during wintertime inversions by advanced factor analysis of aerosol mass spectra, Environ. Sci. Technol., 42, 214-220, 2008b.

Lanz, V. A., Hueglin, C., and Prévôt, A. S. H.: Transport and ageing of organic aerosols, Geophys. Res. Abstr., 10, EGU2008-A-06928, www.cosis.net/abstracts/EGU2008/06928/ EGU2008-A-06928-1.pdf?PHPSESSID=, 2008c.

Legreid, G., Folini, D., Staehelin, J., Balzani Lööv, J., Steinbacher, M., and Reimann, S.: Measurements of organic trace gases including oxygenated volatile organic compounds at the high alpine site Jungfraujoch (Switzerland): Seasonal variation and source alloctaion, J. Geophys. Res., 113, D05307, doi:10.1029/2007JD00863, 2008.
Li, Y., Campana, M., Reimann, S., Schaub, D., Stemmler, K., Staehelin, J., and Peter, T.: Hydrocarbon concentrations at the Alpine mountain sites Jungfraujoch and Arosa, Atmos. Environ., 39, 1113-1127, 2005.

Lugauer, M., Baltensperger, U., Furger, M., Gaeggeler, H. W., Jost, D. T., Schwikowski, M., and Wanner, H.: Aerosol transport to the high Alpine sites Jungfraujoch (3453 m a.s.1.) and Colle Gnifetti (4452 m a.s.1.), Tellus, 50B, 76-92, 1998.

McCulloch, A. and Midgley, P. M.: The production and global distribution of emissions of trichloroethene, tetrachloroethene and dichloromethane over the period 1988-1992, Atmos. Environ., 30, 601-608, 1996.

McKeen, S. A. and Liu, S. C.: Hydrocarbon ratios and photochemical history of air masses, Geophys. Res. Lett., 20, 2363-2366, 1993.

Mészáros, T., Haszpra, L., and Gelencsér, A.: The assessment of the seasonal contribution of the anthropogenic sources to the carbon monoxide budget in Europe, Atmos. Environ., 38, 4147-4154 2004.

Monks, P. S.: A review of the observations and origins of the spring ozone maximum, Atmos. Environ., 34, 3545-3561, 2000.

Novelli, P. C., Connors, V. S., Reichle, H. G. Jr., et al.: An internally consistent set of globally distributed atmospheric carbon monoxide mixing ratios developed using results from an intercomparison of measurements, J. Geophys. Res., 103(D15), 19285-19293, 1998.

Nyeki, S., Li, F., Weingartner, E., Streit, N., Colbeck, I., Gaeggeler, H. W., and Baltensperger, U.: The background aerosol size distribution in the free troposphere: An analysis of the annual cycle at a high-alpine site, J. Geophys. Res., 103, 31749-31761, 1998.

Ordóñez, C., Brunner, D., Staehelin, J., Hadjinicolaou, P., Pyle, J. A., Jonas, M., Wernli, H., and Prévôt, A. S. H.: Strong influence of lowermost stratospheric ozone on lower free tropospheric ozone changes over Europe, Geophys. Res. Lett., 34, L07805, doi:10.1029/2006GL029113, 2007.

Paatero, P.: Least squares formulation of robust non-negative factor analysis, Chemometr. Intell. Lab., 37, 23-35, 1997.

Paatero, P. and Tapper, U.: Analysis of different modes of factoranalysis as least-squares fit problems, Chemometr. Intell. Lab., 8, 183-194, 1993.

Paatero, P. and Tapper, U.: Positive matrix factorization: a nonnegative factor model with optimal utilization of error estimates of data values, Environmetrics, 5, 111-126, 1994.

Parker, A. E., Monks, P. S., Wyche, K. P., Balzani-Lööv, J. M., Staehelin, J., Reimann, S., Legreid, G., Vollmer, M. K., and Steinbacher, M.: Peroxy radicals in the summer free troposphere: seasonality and heterogeneous loss, Atmos. Chem. Phys., 9, 19892006, 2009, http://www.atmos-chem-phys.net/9/1989/2009/.

Reimann, S., Schaub, D., Stemmler, K., Folini, D., Hill, M., Hofer, P., Buchmann, B. and Simmonds, P. G. and Greally, B. R., and O'Doherty, S.: Halogenated greenhouse gases at the Swiss High Alpine Site of Jungfraujoch (3580 m a.s.1.): Continuous measurements and their use for regional European source allocation, J. Geophys. Res., 109, D5, doi:10.1029/2003JD003923, 2004.

Reimann, S., Manning, A. J., Simmonds, P. G., Cunnold, D. M., Wang, R. H., Li, J. L., McCulloch, A., Prinn, R. G., Huang, J., Weiss, R. F., Fraser, P. J., O’Doherty, S., Greally, B. R., Stemmler, K., Hill, M., and Folini, D.: Low European methyl chloroform emissions inferred from long-term at- 
mospheric measurements, Nature, 433, 506-508, 2005.

Reimann, S., Vollmer, M. K., Folini, D., Steinbacher, M., Hill, M., Buchmann, B., Zander, R., and Mahieu, E.: Longterm observations of anthropogenic halocarbons at the high-alpine site of Jungfraujoch (Switzerland) for assessment of trends and European sources, Sci. Total Environ., 391, 224-231, 2008.

Roberts, J. M., Fehsenfeld, F. C., Liu, S. C., Bollinger, M. J., Hahn, C., Albritton, D. L., and Sievers, R. E.: Measurements of aromatic hydrocarbon ratios and $\mathrm{NO}_{\mathrm{x}}$ concentration in the rural troposphere: Observation of air mass photochemical aging and $\mathrm{NO}_{\mathrm{x}}$ removal, Atmos. Environ., 18, 2421-2432, 1984.

Saarikoski, S., Timonen, H., Saarnio, K., Aurela, M., Järvi, L., Keronen, P., Kerminen, V.-M., and Hillamo, R.: Sources of organic carbon in fine particulate matter in northern European urban air, Atmos. Chem. Phys., 8, 6281-6295, 2008,

http://www.atmos-chem-phys.net/8/6281/2008/.

Sandradewi, J., Prévôt, A. S. H., Szidat, S., Perron, N., Alfarra, M. R., Lanz, V. A., Weingartner, E., and Baltensperger, U.: Using aerosol light absorption measurements for the quantitative determination of wood burning and traffic emission contributions to particulate matter, Environ. Sci. Technol., 42, 3316-3323, 2008.

Seber, G. A. F.: Multivariate observations, Wiley, New York, USA, 1984.

Seibert, P., Kromp-Kolb, H., Baltensperger, U., et al.: In Transport and Transformation of Pollutants in the Troposphere, Academic Publishing, Den Haag, The Netherlands, 689-693,1994.

Seibert, P., Kromp-Kolb, H., Kasper, A., Kalina, M., Puxbaum, H., Jost, D. T., Schwikowski, M., and Baltensperger, U.: Transport of polluted boundary layer air from the Po Valley to high-alpine sites, Atmos. Environ., 32, 3953-3965, 1998.

Shim, C., Wang, Y., Singh, H. B., Blake, D. R., and Guenther, A. B.: Source characteristics of oxygenated volatile organic compounds and hydrogen cyanide, J. Geophys. Res., 112, D10305, doi:10.1029/2006JD007543, 2007.

Simmonds, P. G., O'Doherty, S., Nickless, G., Sturrock, G. A., Swaby, R., Knight, P., Ricketts, J., Woffendin, G., and Smith, R.: Automated gas chromatograph mass spectrometer for routine atmospheric field measurements of the CFC replacement compounds, the hydrofluorocarbons and hydrochlorofluorocarbons, Anal. Chem., 67, 717-723, 1995.

Simmonds, P. G., Manning, A. J., Cunnold, D. M., et al.: Global trends, seasonal cycles, and European emissions of dichloromethane, trichloroethene, and tetrachloroethene from the AGAGE observations at Mace Head, Ireland, and Cape Grim, Tasmania, J. Geophys. Res., 111, D18304, doi:10.1029/2006JD007082, 2006.

Steinbacher, M., Vollmer, M. K., Brunner, D., Henne, S., and Reimann, S.: Quasi-continuous $\mathrm{CH}_{4}, \mathrm{~N}_{2} \mathrm{O}$, and $\mathrm{SF}_{6}$ measurements at the high Alpine site Jungfraujoch (3580 m a.s.l.): influence of transport processes and emissions estimates, in preparation, 2009.
Stohl, A.: Trajectory statistics - a new method to establish sourcereceptor relationships of air pollutants and its application to the transport of particulate sulfate in Europe, Atmos. Environ., 30, 579-587, 1996.

Thoning, K. W., Tans, P. P., and Komhyr, W. D.: Atmospheric carbon dioxide at Mauna Loa Observatory 2. Analysis of the NOAA GMCC Data, 1974-1985, J. Geophys. Res., 94(D6), 8549-8565, 1989.

Vigano, I., van Weelden, H., Holzinger, R., Keppler, F., McLeod, A., and Röckmann, T.: Effect of UV radiation and temperature on the emission of methane from plant biomass and structural components, Biogeosciences, 5, 937-947, 2008, http://www.biogeosciences.net/5/937/2008/.

Walker, S. J., Evans, M. J., Jackson, A. V., Steinbacher, M., Zellweger, C., and McQuaid, J. B.: Processes controlling the concentration of hydroperoxides at Jungfraujoch Observatory, Switzerland, Atmos. Chem. Phys., 6, 5525-5536, 2006, http://www.atmos-chem-phys.net/6/5525/2006/.

White, M. L., Russo, R. S., Zhou, Y., Ambrose, J. L., Haase, K., Frinak, E. K., Varner, R. K., Wingenter, O. W., Mao, H., Talbot, R., and Sive, B. C.: Are biogenic emissions a significant source of summertime atmospheric toluene in the rural Northeastern United States?, Atmos. Chem. Phys., 9, 81-92, 2009, http://www.atmos-chem-phys.net/9/81/2009/.

Zanis, P., Monks, P. S., Green, T. J., Schuepbach, E., Carpenter, L. J., Mills, G. P., Rickard, A. R., Brough, N., and Penkett, S. A.: Seasonal variation of peroxy radicals in the lower free troposphere based on observations from the FREE Tropospheric EXperiments in the Swiss Alps, Geophys. Res. Lett., 30(10), 1497, doi:10.1029/2003GL017122, 2003.

Zanis, P., Ganser, A., Zellweger, C., Henne, S., Steinbacher, M., and Staehelin, J.: Seasonal variability of measured ozone production Efficiencies in the lower free troposphere of Central Europe, Atmos. Chem. Phys., 7, 223-236, 2007, http://www.atmos-chem-phys.net/7/223/2007/.

Zellweger, C., Ammann, M., Buchmann, B., Hofer, P., Lugauer, M., Rüttimann, R., Streit, N., Weingartner, E., and Baltensperger, U. Summertime $\mathrm{NO}_{\mathrm{y}}$ speciation at the Jungfraujoch, $3580 \mathrm{~m}$ above sea level, Switzerland, J. Geophys. Res., 105(D5), 6655-6667, 2003.

Zellweger, C., Forrer, J., Hofer, P., Nyeki, S., Schwarzenbach, B., Weingartner, E., Ammann, M., and Baltensperger, U.: Partitioning of reactive nitrogen $\left(\mathrm{NO}_{\mathrm{y}}\right)$ and dependence on meteorological conditions in the lower free troposphere, Atmos. Chem. Phys., 3, 779-796, 2003, http://www.atmos-chem-phys.net/3/779/2003/. 